\title{
Medium Term Conservation of Several Carnation Accessions Via in Vitro Culture
}

\author{
Kurniawan Budiarto*) and Budi Marwoto \\ Indonesian Ornamental Crops Research Institute, \\ Street Raya Pacet-Ciherang, PO. Box 8 Sdl, Cianjur, West Java 43253 \\ Diterima 12-01-2009 Disetujui 04-08-2010
}

\begin{abstract}
Sufficient genetic diversity is important in carnation breeding program. In vivo conservation of carnation germplasm is considered inefficient due to some technical and economical aspects. In vitro conservation was then, expected to overcome the limitation of in vivo method. The research was conducted to find out the proper media for mediumterm in vitro conservation of several carnation accessions in low temperature storage. A complete factorial experiment with 25 replications was designed to accomplish the combination of two factors. The first factor was six commercial carnation cultivars, namely Pink Maladi, Orange Triumph, Opera, Tundra, Yellow Liberty and Prado Reffit. The second factor was the conservation media i.e. $1 / 2 M S+$ DMSO $3 \%$ and $1 / 2 M S+3 \%$ DMSO + $3 \%$ sucrose and control (MS $0+3 \%$ sucrose). The results showed that in vitro conservation of carnation in low temperature were successfully conducted using $1 / 2 \mathrm{MS}+3 \%$ DMSO and $1 / 2 M S+3 \%$ DMSO $+3 \%$ sucrose without significant variation in all accessions tested up to 10 and 12 months respectively. The increase of death plantlets, however, was detected on the media of $1 / 2 M S+3 \%$ DMSO after 6 months storage with significant decrease in viability hereafter. The existence of sucrose in DMSO media induced root formation and plantlet resistance to low temperature storage.
\end{abstract}

Keywords: accessions, Carnation (Dianthus carryophyllus), in vitro conservation, low temperature storage, media

\section{INTRODUCTION}

Carnation (Dianthus carryophyllus) is one of famous ornamental cut flowers in the world. It belongs to dicotyledonous plants and member of Caryophyllaceae family. The family consists of 80 genera and 2000 species which are either annual or perennial. The origins range from southern Russia to Alpine Greece and the Auvergne mountains of (Holley \& Baker, 1992). The Dianthus species are adapted to the cooler Alpine regions of Europe and Asia, and are also found in Mediterranean coastal regions and up to this moment over 300 Dianthus species have been identified (Jurgens et al., 2003a).

Carnations are generally diploid $(2 n=30)$ plants but tetraploid forms $(4 n=60)$ have also been identified. Triploid carnations were produced for commercial purposes, but the resulting plants were mostly aneuploid. Interestingly, traditional techniques for carnation breeding were developed before the discovery of inheritance by Mendel. In the absence of selfpollination, continuous hybridization has inadvertently resulted in highly heterozygous carnation cultivars for mono-ideotype (Jurgens et al., 2003b).

\footnotetext{
*Telp: +620263 512607

Email: bud1arto@yahoo.com
}

The desirable character was improved, while some unpreferred characters were systematically swept out. These dynamic trends have also hastened the genetic erosion on such plant (Halmagyi \& Deliu, 2007). Therefore, preserving genetic diversity was considered a great deal of emphasis for the future breeding to important characters (Poulos, 1993). Originated from subtropics and clonally propagated in commercial, carnation was referred to a limited life span plant in intact condition (Nugent et al., 1991). In the tropic, the conservation of such plant in active growth and in vivo conditions would be very laborious, expensive, and accompanying risks associated field such as pathogens, pests, climatic perturbation and human error (Fukai, 1992).

In vitro conservation was considered to be one promising methods in preserving the collection and reduced the limitation of in vivo conservation. This method was usually conducted using cell growth inhibitor and protectant. The growth inhibitor suppressed the cells growth and controlled the plant size in culture flask, while cell protectant kept the cells from all the factors which would affect the viability of the cell or plantlet in low temperature during storage (Panis \& Lambardi, 2005). 
The growth inhibitors for in vitro conservation were usually divided into osmotic pressure, nutrient modification and growth regulators. Osmotic pressure and nutrient modification were mostly used due to the deleterious effects of particular regulators on cell viability in long period storage (Ashmore et al., 2007). The cell protectant was also divided into permeating and non permeating agents. The non permeating compounds included sugar alcohol, high molecular weight additives, polyvinylpyrolidone, polyethylene glycerol (PEG), dextran, hydroxyethyl starch, etc and the most commonly used permeating additives were dymethylsulfoxide (DMSO) and glycerol. DMSO permeated into cells thus, protected cells more rapidly than glycerol, however, in regards to the toxicity, at equimolar concentration glycerol was less toxic than DMSO (Klavina et al., 2004). Previous study on the use of DMSO for in vitro conservation of several plants indicated that the higher concentration resulted in varying degrees of cytotoxicity. Thus, the range of $2-$ $10 \%$ was the considerably adequate for most plants (Engelmann, 2004). Considering the possibility of the use of nutrient modification and cell protectant, then a medium term in vitro conservation of carnation was studied. The objective of the experiment was to find out the in vitro conservation method by media modification and supplemental DMSO for carnation in low temperature storage.

\section{MATERIALS AND METHODS}

The research was conducted in the tissue culture laboratory at the Indonesian Ornamental Crops Research Institute from June 2006 to August 2007. A complete factorial experiment with 25 replications was designed to accomplish the combination of two factors. The first factor was six commercial carnation cultivars, namely Pink Maladi, Orange Triumph, Opera, Tundra, Yellow Liberty and Prado Reffit. The second factor was different composition of conservation media, comprised of $1 / 2 \mathrm{MS}$ (Murashige \& Skoog) + DMSO $3 \%$ and $1 / 2 \mathrm{MS}$ + DMSO3\% + 3\% sucrose and control (MSO + 3\% sucrose). All the media treatments were solidified with $\operatorname{agar}(7 \mathrm{~g} / \mathrm{l})$.

The rooted cuttings of carnation accessions were collected from commercial nurseries in West Java. The cuttings were then, replanted in $15 \mathrm{~cm}$ pot and maintained in protected glass house provided by twice a week foliar sprays of $2 \mathrm{~g} / \mathrm{l}$ complete fertilizer $(10 \% \mathrm{~N}$,
$7 \% \mathrm{P}, 14 \% \mathrm{~K}, 0.5 \% \mathrm{Mg}, 9 \% \mathrm{Ca}$ and $0.2 \% \mathrm{~S}-$ Tani Mulya, Wes Java). After 2 weeks, the plants were pinched and the new emerging lateral growths served for explants. The explants were disinfected using chemicals, then planted and subcultured into defined medium according to Budiarto et al., (2008) to obtain uniform plantlets.

After three weeks subculture, 2 node-apical of plantlet was excised into treatment media and placed into growth chamber under the temperature of $18-21^{\circ} \mathrm{C}$. After three days, the plantlets were then preconditioned by lowering the temperature gradually, $\pm 2^{\circ} \mathrm{C}$ every two days, until constant temperature of $4^{\circ} \mathrm{C}$. The viability of plantlets was evaluated and checked every two months during 12 months storage by subculturing the plantlet into induction medium. Prior to subculture, the culture flasks were placed into growth chamber with gradual increase of temperature up to $16-18^{\circ} \mathrm{C}$ in six days. The observation was conducted on the survival rate, viability of planlets after storage and other distinct phenomena related to the treatment being applied. The data gathered were analyzed using ANOVA and LSD (Least Significant Difference) test (á $=5 \%)$.

\section{RESULT AND DISCUSSION}

Analysis of variances of factors studied revealed that no significant variation existed on carnation accessions on the survival rate and viability of plantlets on every two months evaluation during 12 months of storage. The interaction between conservation media and carnation accessions was not also detected in all parameters observed.

Survival rate and planlet viability. Table 1 presented the percentage of plantlet survival rates and viability every two months evaluation during 12 months storage. Data on Table 1 showed that plantlet survival rates and viability were decrease significantly on MS 0 $+3 \%$ sucrose compared to those conserved in $1 / 2 \mathrm{MS}+$ $3 \%$ DMSO and $1 / 2 \mathrm{MS}+3 \%$ DMSO $+3 \%$ sucrose during the first two months of storage. The death of all plantlets corresponding to the death of cells on MS 0 was detected subsequently after two months, while those in $1 / 2 \mathrm{MS}+3 \%$ DMSO and $1 / 2 \mathrm{MS}+3 \%$ DMSO + $3 \%$ sucrose decreased slightly.

The lower plantlets survival rates and viability of carnation planted in MS 0 during the early storage and the death of all plantlets after two months indicated that during low temperature storage, the cell biological 
system was disturbed and these caused physiological disturbance. The prolonged extreme low temperature then, resulted in loss of cell turgidity and viability, thus finally caused the death of cells and plantlets (Dereuddre et al., 2004). These situations also inferred that though sucrose was also known for preservative additives by inducing partial dehydration of cells and had successfully used for low temperature storage of several plants such as Acer pseudoplatanus, Casicum annum, Nicotiana tabaccum and Nicotiana plumbaginifolia (Whiters \& Streets, 1977; Maddox et al., 1982/1983), the mode of protection could not counteract alone the inherent developmental and physiological differences found in specific plant. Several indications were also reported the failure of single treatment of sucrose as protectant during low temperature storage of coffee (Bertrand-Desbrunais et al., 1988), Picea abis (Garlene \& Dereuddre, 1987) and sweet orange (Marin \& Duran-Villa, 1988).

Opposite with these situations, the plantlet preserved in $1 / 2 \mathrm{MS}+3 \%$ DMSO and $1 / 2 \mathrm{MS}+3 \%$ DMSO $+3 \%$ sucrose survived in prolonged period up to 10 and 12 months respectively in low temperature storage (Table 1). These situations indicated that the supplemental DMSO in the media influenced the plantlet resistance to low temperature condition by increasing the cell retention more effectively against such conditions than single treatment of sucrose.
DMSO induced the reduction of cell volume and water content (Fukai et al., 2004) and elicited membrane configuration (Fukai, 1992). In these conditions, the cells were exposed to adjust the osmotic imbalance between outer and inner parts by electrolyte accumulation within the cells (Zao et al., 2005) and the injurious level of dehydration was prevented by the modified cell membrane (Hitmi et al., 2000a).

The existence of sucrose in DMSOconservation media. The decrease of plantlet survival rate and viability of carnation on the media of $1 / 2 \mathrm{MS}+$ $3 \%$ DMSO were significantly detected after 6 and 8 months storage respectively (Table 1), while those in $1 / 2 \mathrm{MS}+3 \%$ DMSO $+3 \%$ sucrose still showed higher survival rate and viability during these period. The significant increase of death plantlets in the media of $1 / 2 \mathrm{MS}+3 \%$ DMSO $+3 \%$ sucrose was observed after 8 months storage with starting viability loss after 10 months storage. However, the viability of plantlets in this media was still relatively high (>50\%) after 12 months storage. These situations collided with the ambiguous complex mechanism of sucrose in increasing plantlet resistance to low temperature during storage. When DMSO was absent in MS 0 , the plantlets were not able to make use of sucrose in the media to prevent the optimal growth and resulted in the death of planlet (Figure 1). In contrast, when the cell protectant could reduce the negative effects of low temperature

Table 1. Percentage of survival rate and plantlet viability of carnation accessions on different in vitro culture media

\begin{tabular}{|c|c|c|c|c|c|c|c|c|c|c|c|}
\hline \multirow{2}{*}{ Media composition } & \multicolumn{11}{|c|}{ Observation after.........months storage } \\
\hline & \multicolumn{2}{|l|}{2} & \multicolumn{2}{|l|}{4} & \multicolumn{2}{|c|}{6} & \multicolumn{2}{|l|}{8} & 10 & \multicolumn{2}{|c|}{12} \\
\hline \multicolumn{12}{|l|}{ Survival rates (\%) } \\
\hline MS $0+3 \%$ sucrose (control) & 55.2 & a & 0 & a & 0 & a & 0 & a & a & 0 & $a$ \\
\hline $1 / 2 \mathrm{MS}+3 \% \mathrm{DMSO}$ & 100 & b & 91.2 & b & 73.3 & b & 22.3 & b & 17.1 & 0 & a \\
\hline $1 / 2 \mathrm{MS}+3 \%$ DMSO $+3 \%$ sucrose & 100 & b & 93.6 & $\mathrm{~b}$ & 83.1 & $\mathrm{C}$ & 65.4 & $\mathrm{C}$ & 44.6 & 16.8 & $\mathrm{~b}$ \\
\hline CV $(\%)$ & \multicolumn{2}{|c|}{8.13} & \multicolumn{2}{|c|}{10.37} & \multicolumn{2}{|c|}{11.42} & \multicolumn{2}{|c|}{9.31} & 8.71 & \multicolumn{2}{|c|}{7.27} \\
\hline \multicolumn{12}{|l|}{ Planlet viability (\%) } \\
\hline MS $0+3 \%$ sucrose (control) & 64.6 & a & 0 & a & 0 & a & 0 & a & a & 0 & a \\
\hline $1 / 2 \mathrm{MS}+3 \%$ DMSO & $97.4 k$ & b & 90.2 & b & 83.7 & $b$ & 66.5 & $b$ & $51.3 \mathrm{~b}$ & 0 & a \\
\hline $1 / 2 \mathrm{MS}+3 \%$ DMSO + $3 \%$ sucrose & $100 k$ & $\mathrm{~b}$ & 100 & $\mathrm{~b}$ & 92.7 & C & 83.7 & $\mathrm{C}$ & $77.3 \mathrm{c}$ & 64.2 & $\mathrm{~b}$ \\
\hline CV (\%) & 7.47 & & 6.32 & & 8.67 & & 8.16 & & 9.27 & 7.1 & 13 \\
\hline
\end{tabular}

Values followed by different letters in the same column differ significantly at LSD 5\%
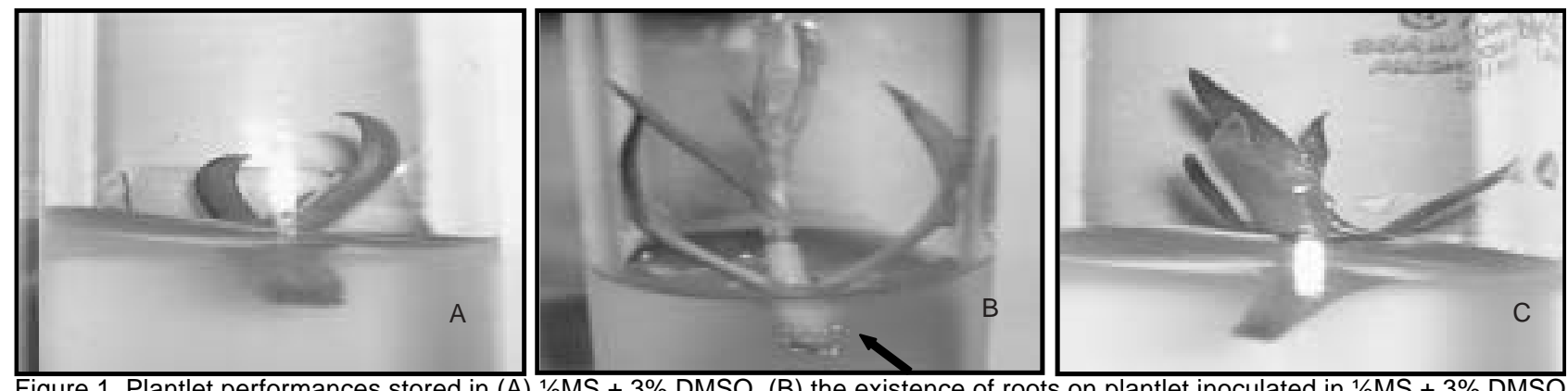

Figure 1. Plantlet performances stored in (A) $1 / 2 \mathrm{MS}+3 \%$ DMSO, $(\mathrm{B})$ the existence of roots on plantlet inoculated in $1 / 2 \mathrm{MS}+3 \%$ DMSO $+3 \%$ sucrose (pointing by black arrow) and $(\mathrm{C})$ the plantlet death on the MS 0 media in 4 months after low temperature storage 
and the cells/plantlet were able to survive by maintaining the modified physiological status, the existence of sucrose seemed to be the limiting factor in the prolonged storage-plantlet survival.

The appearance of roots was also detected after 4 months of storage (Figure 1) in all carnation accessions stored in $1 / 2 \mathrm{MS}+3 \% \mathrm{DMSO}+3 \%$ sucrose and the further root growth were observed after then. No root formation was found in all cultivars grown in the absence of carbon source $(1 / 2 \mathrm{MS}+3 \% \mathrm{DMSO})$. Sucrose is well known to be the major carbon source in plant tissue media. Thus, on the existence of sucrose, the protected plantlets were sufficiently supplied with organic carbon as the source of energy (Hitmi et al., 2000b) by maintaining function of absorbing organ. These situations were predictably induced higher resistance of plantlets to low temperature than those stored in $1 / 2 \mathrm{MS}+3 \%$ DMSO.

\section{CONCLUSIONS}

In vitro conservation of carnation accessions in low temperature were successfully conducted using solidified media containing $1 / 2 \mathrm{MS}+3 \%$ DMSO and $1 / 2$ $\mathrm{MS}+3 \% \mathrm{DMSO}+3 \%$ sucrose without significant variation on all the accessions tested up to 10 and 12 months respectively.

The increase of death plantlets in the media of $1 / 2 \mathrm{MS}$ $+3 \%$ DMSO was detected after 6 months storage with significant decrease in viability, while those in $1 / 2 \mathrm{MS}+$ $3 \%$ DMSO + 3\% sucrose were lengthened.

Supplemental carbon source in DMSO media induced root formation and plantlet resistance to low temperature during storage.

\section{ACKNOWLEDGEMENT}

The authors would like to thank to Prof. Dr. Teresita L. Rosario, Departement of Horticulture, The University of The Philippines at Los Banos for her valuable assistance, criticms and suggestions during the conduct of the research and preparation of the article.

\section{REFERENCES}

Ashmore, S.E., Drew, R.A. \& Azimi. M. 2007. Vitrificationbased shoot tip cryopreservation of Carica papaya and a wild relative Vasconcellea pubescens. Aus. Journal of Bot 55 (5): 541-547.

Budiarto, K., Rahardjo, I.B. \& Sulyo, Y. 2008. Durasi pemanasan pada suhu $38-40^{\circ} \mathrm{C}$ untuk pembebasan varietas anyelir dar infeksi virus CarMV. Journal Hort. Ed. Khusus (1): 38-44
Bertrand-Desbrunais, A., Fabre, J., Engelmann, F., Dereuddre, J. \& Charrier, A. 1988. Reprise de l'embryogene adventive d'embryos somatique de cafeier (Coffea arabica) apres leur congelation dans l'azote liquide. C. R. Acad. Sci. Paris. Ser. III 307: 795-801.

Dereuddre, J., Fabre, J. \& Bassaglia, C. 2004. Resistance to freezing in liquid nitrogen of carnation (Dianthus caryophyllus L. var. Eolo) apical and axillary shoot tips excised from different aged in vitro plantlets. Plt. Cell. Rep 7(3): 170-173.

Engelmann, F. 2004. In vitro conservation of tropical plant germplasm-a review. Euphytica 57(3): 227-243.

Fukai, S. 1992. Studies on the cryopreservation of shoot tips of Dianthus and Chrysanthemum. Mem. Fac Agric, Kagawa Univ 56: $1-7$.

Fukai, S., Goi, M. \& Tanaka, M. 2004. Cryopreservation of shoot tips of Caryophyllaceae ornamentals. Euphytica 56(2): 149153

Garlene, M. \& Dereuddre, J. 1987. Survive de cals embryogenes d'epicea après congelation a $-196^{\circ} \mathrm{C}$. Extrait de Annales. AFOCEL 133p.

Halmagyi, A. \& Deliu, C. 2007. Cryopreservation of carnation (Dianthus caryophyllus L.) shoot tips by encapsulationvitrification. Scientiae Hortic 113(3): 300-306.

Hitmi, A., Barthomeuf, C. \& Sallanon, H. 2000a. Role of intracellular water retention strength in freezing tolerance of Chrysanthemum cinerariaefolium vis cell cultures. J. Plant Physiol 157: 47-53.

Hitmi, A., Barthomeuf, C. \& Sallanon, H. 2000 b. Cryopreservation of Chrysanthemum cinerariaefolium shoot tips. J. Plant Physiol 156: 408-412.

Holley, W.D., \& Baker, R. 1992. Breeding for better varieties. Chapter 3. In: Holley, W. D. and R Baker, (eds) . Carnation Production II. Colorado State University 21-30p.

Jurgens, A., Witt, T. \& Gottsberger, G. 2003a. Flower scent composition in Dianthus and Saponaria species. Biochem. Sytematics and Eco 31: 345-357.

Jurgens, A., Witt, T. \& Gottsberger, G. 2003b. Pollen grain numbers, ovule numbers and pollen-ovule ratios in Caryophylloideae; correlation with breeding system, pollination, life form, style number and sexual system. Sex. Plt. Reprod 14: 279-289.

Klaviña, D., Gailîte, A., Jakobsone, G., Neçajeva, J. \& Gavrilova, G. 2004. Tissue culture technology in conservation of threatened plant species of Latvia. Acta Universitatis Latviensis, Biology 676: 183-188.

Maddox, A.D., Gonsalves, F.G. \& Shields, R. 1982/1983. Successful cryopreservation of suspension cultures of three Nicotiana species at the temperature of liquid nitrogen. Plant Sci. Lett 28: 157-162.

Marin, M.L. \& Duran-Villa, N. 1988. Survival of somatic embryos and recovery of plants of sweet orange (Citrus sinensis L. Osb.) PIt. Cell Tissue Org. Cult 14: 51-57.

Nugent, G., Wardley-Richardon, T. \& Lu, C.Y. 1991. Plant regeneration from stem and petal of carnation (Dianthus caryophyllus L.). Plt. Cell Rep 10: 477-480.

Panis, B. \& Lambardi, M. 2005. Status of cryopreservation in plants (crops and forest trees). Symp. The Role of Biotech. Villa Guallino, Italy, 5-7 March 6-9p.

Poulos, J.M. 1993. Germplasm evaluation and utilization. In: Germplasm collection, evaluation, documentation and conservation. AVRDC, Shanhua, Taiwan, ROC 69-74p.

Whitters, L.A. \& H.E. Streets. 1977. Freeze-preservation of cultured plant cells, III: The pregrowth phase. Physiol. Plant 39: 171-178.

Zhao, M.A., Xhu, Y.Z., Dhital, S.P., Khu, D. M. Song, Y.S., Wang, M.Y. \& Lim, H. T. 2005. An efficient cryopreservation procedure for potato (Solanum tuberosum L.) utilizing the new ice blocking agent, Supercool X1000. Plt. Cell Rep. 24(8): 477-481. 